Indonesian Journal of Human Nutrition

P-ISSN 2442-6636

E-ISSN 2355-3987

www.ijhn.ub.ac.id

Artikel Hasil Penelitian

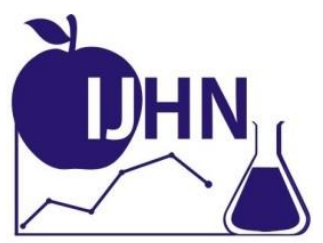

\title{
Perbandingan Faktor Pertumbuhan dan Sitokin Air Susu Ibu (ASI) Neonatus Prematur dengan Neonatus Aterm
}

\author{
Anik Puryatni ${ }^{1}$, Prasetya Ismail Permadi ${ }^{1}$ \\ ${ }^{1}$ Departemen Ilmu Kesehatan Anak-Fakultas Kedokteran Universitas Brawijaya \\ * Alamat korespondensi: anik.puryatni@gmail.com
}

Diterima: September 2020

Direview: April 2021

Dimuat: Juli 2021

\begin{abstract}
Abstrak
Air Susu Ibu (ASI) mengandung berbagai komponen biologis aktif, yang berfungsi sebagai nutrisi, maturasi saluran cerna, dan pertahanan saluran pencernaan neonatus. Peran ASI dalam pertahanan (barrier) saluran pencernaan, diperankan oleh growth factors dan sitokin. Penelitian ini bertujuan untuk mengetahui perbedaan kadar faktor pertumbuhan dan sitokin ASI menurut kelompok usia kehamilan neonatus dan jenis tahapan ASI. Penelitian menggunakan desain deskriptif analitik, dengan metode potong lintang dengan consecutive sampling. Sampel dibagi menjadi empat kelompok yakni kelompok neonatus extremely preterm $(\mathrm{n}=6)$, very preterm $(\mathrm{n}=6)$, mild preterm $(\mathrm{n}=6)$, dan kelompok neonatus aterm $(\mathrm{n}=6)$. Dilakukan pengukuran kadar faktor pertumbuhan dan sitokin dari sampel ASI kolostrum (hari ke-3 pasca persalinan) dan ASI transisi (hari ke-10 pasca persalinan). Hasil penelitian menunjukkan bahwa kadar IGF-1 ( $\mathrm{p}=0,05)$, EGF, hBD-1, hBD-2 dan IL-8 $(p=0,00)$ berbeda bermakna antar kelompok penelitian. Kadar IGF-1 $(p=0,03)$, EGF $(p=0,00)$, dan hBD-1 $(\mathrm{p}=0,02)$ berbeda bermakna antara ASI kolostrum dan ASI transisi. Maka dapat disimpulkan berdasarkan hasil penelitian ini terdapat perbedaan kadar faktor pertumbuhan IGF-1, EGF dan hBD-1 antara neonatus prematur dan aterm berdasarkan jenis tahapan ASI
\end{abstract}

Kata kunci: ASI, faktor pertumbuhan, sitokin, neonatus

\begin{abstract}
Breast milk contains various biologically active components that function as nutrition, gastrointestinal maturation, and the neonate's digestive tract defense. The role of breast milk in the defense (barrier) of the digestive tract is affected by growth factors and cytokines. This study aims to determine the differences in growth factor and cytokine levels in breast milk according to the gestational age group and the types of breastfeeding stages. The study used a descriptive-analytic design with a cross-sectional method with consecutive sampling. The sample was divided into four groups, namely extremely preterm $(n=6)$, very preterm $(n=6)$, mild preterm $(n=6)$, and aterm neonate $(n=6)$. Measurements of growth factor and cytokine levels were performed from samples of colostrum breast milk ( $3^{\text {rd }}$ day postpartum) and transitional breast milk $\left(10^{\text {th }}\right.$ day postpartum). The results show that the levels of IGF-1 ( $p=0.05), E G F, h B D-1, h B D-2$, and $I L-8(p=0.00)$ are significantly different between the study groups. The levels of IGF-1 ( $p=0.03), E G F(p=0.00)$, and hBD-1 ( $p=0.02)$ are significantly different between colostrum and transitional breast milk. In conclusion, there are differences in the levels of IGF-1, EGF, and hBD-1 growth factors between preterm and aterm neonates based on the type of breast milk stages.
\end{abstract}

Keywords: breast milk, cytokines, growth factors, neonates 


\section{PENDAHULUAN}

Air Susu Ibu (ASI) memberikan kekebalan pasif pada saluran cerna neonatus melalui peran faktor kekebalan tubuh yang terkandung di dalamnya. ASI mengandung komponen biologis aktif, yang berfungsi memberikan nutrisi dan membantu maturasi saluran pencernaan neonatus [1-3]. Selain pada saluran cerna, ASI juga memilki efek biologis terhadap sistem pembuluh darah, susunan saraf, endokrin, dan sistem imun. Fungsi pertahanan (barrier) saluran pencernaan, antar lain diperankan oleh growth factors dan sitokin (IL-1 $\beta$, IL-6, TNF- $\alpha$, TGF- $\beta 1$, and TGF- $\beta 2$ ) [4].

Konsentrasi growth factors dan sitokin yang rendah pada ASI menjadi faktor risiko terjadinya sepsis pada neonatus prematur, namun konsentrasi detil faktor-faktor tersebut pada ASI dari ibu neonatus cukup bulan maupun prematur belum banyak diteliti. Penelitian sebelumnya telah mengkaji hubungan antara dosis konsumsi ASI dengan penurunan kejadian sepsis neonatorum [5], dan korelasi usia gestasi dengan kadar antimicrobial protein/ peptides (AMP) [6,7].

Growth factor dalam ASI yang diketahui memiliki peran signifikan pada maturitas saluran cerna neonatus adalah Insulin-like Growth Factor-I (IGF-I), Epithelial Growth Factor (EGF), human $\beta$-defensin 1 dan 2 (hBD-1 dan hBD-2), serta IL-8. Penelitian yang membuktikan kadar faktor pertumbuhan dan sitokin pada ASI khususnya neonatus prematur sesuai tahapan laktasinya masih terbatas. Penelitian ini bertujuan untuk mengetahui hubungan antara usia gestasi dengan kadar faktor pertumbuhan dan sitokin dalam ASI.

\section{METODE PENELITIAN \\ Desain Penelitian}

Penelitian ini merupakan penelitian deskriptif analitik [8], untuk mengetahui perbedaan kadar faktor pertumbuhan dan sitokin (IGF-1, EGF, hBD-1, hBD-1 dan IL-8) ASI kolostrum dan ASI transisi pada ibu dengan neonatus prematur atau aterm yang mendapatkan asupan ASI. Penelitian dilakukan bulan Maret hingga April tahun 2019 di ruang perinatologi Rumah Sakit Umum Daerah Dr. Saiful Anwar (RSSA) dan Laboratorium Faal Fakultas Kedokteran Universitas Brawijaya Malang. Penelitian ini telah mendapatkan persetujuan dari tim Kelaikan Etik RSU Dr. Saiful Anwar Malang, no: 400/268/K.3/302/2019.

Subyek penelitian yaitu pasangan ibu dengan neonatus prematur (usia gestasi <37 minggu) atau neonatus aterm (usia gestasi 37 sampai <42 minggu). Sampel yang digunakan dalam penelitian ini adalah sampel ASI kolostrum (hari ke-3 pasca persalinan) dan ASI transisi (hari ke-10 pasca persalinan). Sampel diambil dengan metode consecutive sampling.

Kriteria inklusi sampel penelitian sebagai berikut: 1) Pasangan ibu dan neonatus prematur/aterm yang mendapatkan ASI, dan 2) Ibu bersedia ikut serta dalam penelitian dengan menandatangani informed consent. Neonatus dieksklusi dari penelitian bila menderita kelainan bawaan mayor dan kelainan bedah pada saluran pencernaan. Sampel penelitian dibagi menjadi 4 kelompok, yakni kelompok neonatus extremely preterm ( $<28$ minggu), very preterm (28 sampai 32 minggu), mild preterm (32 sampai 37 minggu), dan kelompok neonatus aterm (37 sampai 42 minggu) 
Pengukuran Kadar Faktor Pertumbuhan dan Sitokin pada ASI

Sampel ASI dikumpulkan secara serial dari ibu dengan neonatus prematur atau aterm pada hari ke-3 pasca persalinan (sampel ASI kolostrum) dan pada hari ke-10 pasca persalinan (sampel ASI transisi). Kadar faktor pertumbuhan dan sitokin diukur dengan metode enzyme-linked immunosorbent assay (ELISA) menggunakan Quantikine Human ELISA kit IGF-1, EGF, hBD-1, hBD-2, dan IL-8 sesuai manual kit [10-13]. Antibodi primer yang digunakan adalah Anti IGF-1, anti EGF, anti hBD-1, anti hBD-2 dan anti IL-8 (R\&D Systems) dan antibodi sekunder Antirabbit/Antigoat IgG (R\&D Systems) dengan pengenceran 1:1000, dan deteksi dilakukan dengan reaksi horse radish peroksidase (SA-HRP). Absorbansi larutan kemudian diukur dengan ELISA reader pada panjang gelombang $450 \mathrm{~nm}$, dan dinyatakan dalam satuan $\mathrm{ng} / \mathrm{ml}$ untuk faktor pertumbuhan IGF-1, EGF, hBD-1, hBD-2 dan pg/ml untuk sitokin IL-8 [8-11]. Alur penelitian ini sebagai berikut:

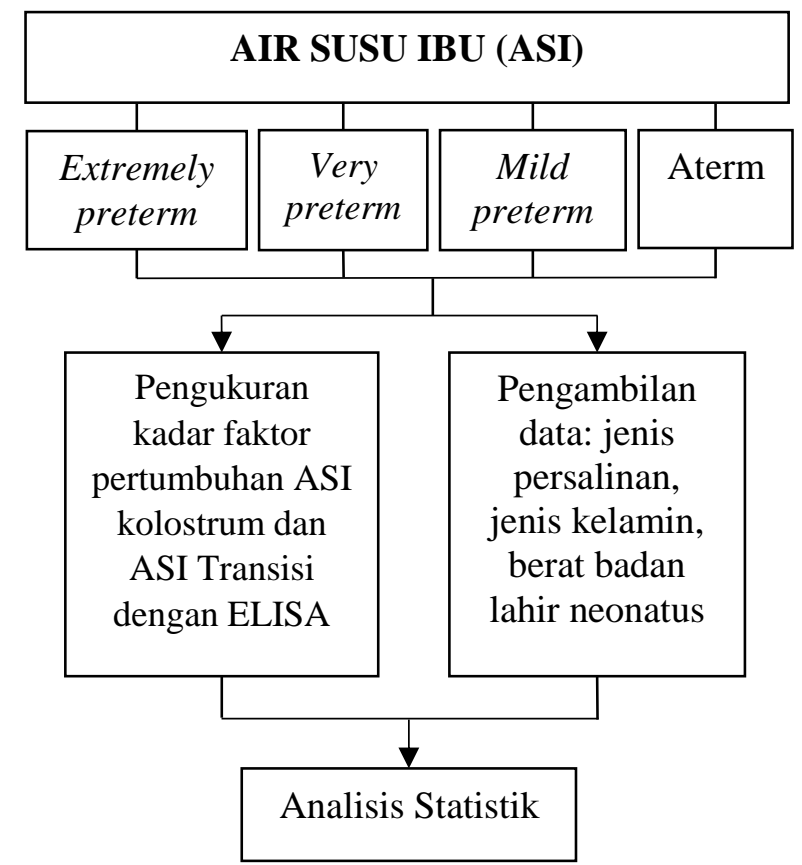

Gambar 1. Alur penelitian

\section{Analisis Data}

Analisis statistik menggunakan SPSS 26.0. Uji Shapiro-Wilk digunakan untuk uji normalitas, uji homogenitas sampel, uji MANOVA untuk mengetahui perbandingan kadar faktor pertumbuhan dan sitokin antar kelompok penelitian, uji korelasi Pearson untuk mengetahui korelasi antar variabel faktor pertumbuhan dan sitokin dengan usia kehamilan, uji $\mathrm{T}$ berpasangan untuk mengetahui perbedaan kadar faktor pertumbuhan dan sitokin antara ASI kolostrum dan ASI transisi. Uji statistik dilakukan pada derajat kepercayaan $95 \%$ dengan $\alpha=0,05$. Hasil uji statistik dinyatakan bermakna bila $\mathrm{p}<0,05$ [12].

\section{HASIL PENELITIAN \\ Karakteristik Subyek Penelitian}

Karakteristik sampel pada penelitian ini dapat dilihat pada Tabel 1. Karakteristik sampel menunjukkan ada perbedaan bermakna antar kelompok usia 
kehamilan (prematuritas) dengan faktor ibu yaitu tingkat pendidikan $(\mathrm{p}=0,01)$, jenis persalinan $(\mathrm{p}=0,01)$ dan kejadian preeklampsia $(\mathrm{p}=0,01)$ serta faktor bayi yaitu berat badan lahir rendah $(\mathrm{p}=0,00)$ dan IMD $(\mathrm{p}=0,01)$.

\section{Tabel 1. Karakteristik subyek penelitian}

\begin{tabular}{|c|c|c|}
\hline Karakteristik & Jumlah & P-Value \\
\hline \multicolumn{3}{|l|}{ Faktor Ibu } \\
\hline \multicolumn{3}{|l|}{ Usia: } \\
\hline$<17$ tahun & $0 / 24$ & 0,24 \\
\hline $17-35$ tahun & $21 / 24$ & \\
\hline$>35$ tahun & $3 / 24$ & \\
\hline \multicolumn{3}{|l|}{ Indeks Massa tubuh (IMT) } \\
\hline$<18,5$ & $0 / 24$ & 0,68 \\
\hline $18,5-24,9$ & $11 / 24$ & \\
\hline $25-29,9$ & $7 / 24$ & \\
\hline$>30$ & $6 / 24$ & \\
\hline \multicolumn{3}{|l|}{ Pendidikan: } \\
\hline SD & $4 / 24$ & 0,01 \\
\hline SMP & $5 / 24$ & \\
\hline SMA & $6 / 24$ & \\
\hline Diploma/sarjana & $9 / 24$ & \\
\hline \multicolumn{3}{|l|}{ Pekerjaan: } \\
\hline Tidak bekerja/IRT & $12 / 24$ & 0,50 \\
\hline Bekerja & $12 / 24$ & \\
\hline \multicolumn{3}{|l|}{ Paritas: } \\
\hline Primipara & $4 / 24$ & 0,14 \\
\hline Multipara & $20 / 24$ & \\
\hline \multicolumn{3}{|l|}{ Persalinan: } \\
\hline Spontan & $9 / 24$ & 0,02 \\
\hline Seksio sesaria & $15 / 24$ & \\
\hline \multicolumn{3}{|l|}{ Perokok Aktif: } \\
\hline Ya & $3 / 24$ & 0,02 \\
\hline Tidak & $21 / 24$ & \\
\hline \multicolumn{3}{|l|}{ Perokok Pasif: } \\
\hline Ya & $21 / 24$ & 0,77 \\
\hline Tidak & $3 / 24$ & \\
\hline \multicolumn{3}{|l|}{ Preeklamsia/eklamsia: } \\
\hline Ya & $5 / 24$ & 0,00 \\
\hline Tidak & $19 / 24$ & \\
\hline \multicolumn{3}{|l|}{ Faktor Neonatus } \\
\hline \multicolumn{3}{|l|}{ Jenis Kelamin: } \\
\hline Laki-laki & $8 / 24$ & 0,21 \\
\hline Perempuan & $16 / 24$ & \\
\hline \multicolumn{3}{|l|}{ Berat Badan Lahir: } \\
\hline$<2500$ gram & $18 / 24$ & 0,00 \\
\hline$\geq 2500$ gram & $6 / 24$ & \\
\hline \multicolumn{3}{|l|}{ Skor APGAR menit ke-5 } \\
\hline$<7$ & $7 / 24$ & 0,07 \\
\hline$\geq 7$ & $17 / 24$ & \\
\hline \multicolumn{3}{|l|}{ Inisiasi Menyusui Dini } \\
\hline $\mathrm{Ya}$ & $8 / 24$ & 0,02 \\
\hline Tidak & $16 / 24$ & \\
\hline
\end{tabular}

Nilai signifikansi bila $\mathrm{P}<0,05$ 
Kadar Faktor Pertumbuhan dan Sitokin

Hasil penelitian ini, dari Uji MANOVA menunjukkan perbedaan kadar faktor pertumbuhan dan sitokin IGF-1 $(p=0,05)$, EGF $(p=0,00)$, hBD-1 $(\mathrm{p}=0,00), \quad$ hBD-2 $\quad(\mathrm{p}=0,00)$ dan $\quad \mathrm{IL}-8$ $(\mathrm{p}=0,00)$ antar kelompok usia kehamilan. Dari uji korelasi Pearson untuk mengetahui hubungan antara kadar faktor pertumbuhan dan sitokin dengan usia kehamilan menunjukkan hubungan antara kadar hBD-1 $(\mathrm{p}=0,000, \mathrm{r}=0,515)$ dan hBD-2 ( $\mathrm{p}=0,001, \mathrm{r}=-0,464)$ dengan usia kehamilan, kadar IGF-1 dengan IL-8 $(\mathrm{p}=0,003, \mathrm{r}=-0,425)$, kadar EGF dengan hBD-1 ( $\mathrm{p}=0,001, \mathrm{r}=-0,456)$, kadar hBD-1 dengan IL-8 $(p=0,035, r=-0,306)$.

Dari uji $\mathrm{T}$ berpasangan untuk mengetahui perbedaan kadar faktor pertumbuhan antara ASI kolostrum dan ASI transisi menunjukkan perbedaan kadar faktor pertumbuhan IGF-1 $(p=0,03)$, EGF $(p=0,00)$, dan hBD-1 $(\mathrm{p}=0,02)$. Kadar hBD-2 $(\mathrm{p}=0,14)$ dan IL-8 $(\mathrm{p}=0,07)$ tidak berbeda bermakna.

Kadar IGF-1 tren meningkat seiring dengan peningkatan usia kehamilan. Kadar EGF tren menurun dengan puncak di kelompok usia 32-37 minggu, kemudian meningkat pesat dengan puncak di kelompok usia 37-42 minggu. Kadar hBD-1 tren meningkat pada kelompok usia 32-37 minggu dan puncaknya pada kelompok usia 37-42 minggu. Kadar hBD-2 dan IL-8 tren turun mendatar dibandingkan dengan kadar tinggi di awal (Tabel 2).

Tabel 2. Kadar faktor pertumbuhan dan sitokin pada ASI

\begin{tabular}{|c|c|c|c|c|c|c|}
\hline \multirow{2}{*}{\multicolumn{2}{|c|}{$\begin{array}{l}\text { Faktor pertumbuhan } \\
\text { dan sitokin }\end{array}$}} & \multicolumn{4}{|c|}{ Kelompok neonatus berdasarkan usia gestasi } & \multirow[b]{2}{*}{$\begin{array}{c}\text { P-Val } \\
\text { ue }\end{array}$} \\
\hline & & \multirow[t]{2}{*}{$\begin{array}{l}<28 \text { minggu } \\
(\mathrm{n}=6)\end{array}$} & \multirow[t]{2}{*}{$\begin{array}{c}\text { 28-32 minggu } \\
(\mathrm{n}=6)\end{array}$} & \multirow[t]{2}{*}{$\begin{array}{c}\text { 32-37 minggu } \\
(\mathrm{n}=6)\end{array}$} & \multirow[t]{2}{*}{$\begin{array}{c}\text { 37-42 minggu } \\
(\mathrm{n}=6)\end{array}$} & \\
\hline \multicolumn{3}{|c|}{ ASI Kolostrum } & & & & \\
\hline \multicolumn{7}{|c|}{ A Faktor Pertumbuhan } \\
\hline & IGF-1 (ng/mL) & $1,6 \pm 0,49$ & $1,8 \pm 1,1$ & $1,9 \pm 1.1$ & $2,7 \pm 0,9$ & 0,25 \\
\hline & EGF (ng/mL) & $508,4 \pm 95,4$ & $419,0 \pm 99,6$ & $169,7 \pm 31.2$ & $776,3 \pm 418,0$ & 0,00 \\
\hline & hBD-1 (ng/mL) & $205,0 \pm 66,3$ & $151,6 \pm 137,5$ & $116,3 \pm 87,8$ & $594,7 \pm 458,0$ & 0,01 \\
\hline & hBD-2 (ng/mL) & $4398,6 \pm 1420,5$ & $3014,5 \pm 2023,4$ & $2630,3 \pm 1598.2$ & $1277,0 \pm 709,9$ & 0,05 \\
\hline \multicolumn{7}{|c|}{ B Sitokin } \\
\hline & IL-8 $\quad(\mathrm{pg} / \mathrm{mL})$ & $512,0 \pm 150,2$ & $396,2 \pm 101,3$ & $487,6 \pm 82.3$ & $546,5 \pm 55,0$ & 0,10 \\
\hline \multicolumn{7}{|c|}{ ASI Transisi } \\
\hline \multicolumn{7}{|c|}{ A Faktor Pertumbuhan } \\
\hline & IGF-1 (ng/mL) & $2,4 \pm 1,1$ & $1,5 \pm 0,2$ & $2,2 \pm 0,7$ & $2,5 \pm 0,7$ & 0,15 \\
\hline & EGF (ng/mL) & $510,6 \pm 87,7$ & $421,32 \pm 186,51$ & $228,8 \pm 114,4$ & $645,5 \pm 141,1$ & 0,00 \\
\hline & hBD-1 (ng/mL) & $107,2 \pm 55,1$ & $109,3 \pm 64,5$ & $169,7 \pm 116,8$ & $506,8 \pm 267,3$ & 0,00 \\
\hline & hBD-2 (ng/mL) & $5287,0 \pm 727,1$ & $2237,4 \pm 1824,3$ & $2173,7 \pm 1517,4$ & $3170,3 \pm 1699,4$ & 0,00 \\
\hline \multirow[t]{2}{*}{ B } & Sitokin & & & & & \\
\hline & IL-8 $\quad(\mathrm{pg} / \mathrm{mL})$ & $581,2 \pm 102,4$ & $358,4 \pm 67,9$ & $510,3 \pm 42,9$ & $544,6 \pm 44,4$ & 0,00 \\
\hline
\end{tabular}

\section{PEMBAHASAN}

Menyusui dapat mengurangi morbiditas dan mortalitas bayi. ASI mengandung berbagai faktor pertumbuhan dan faktor antiinfeksi. Faktor pertumbuhan pada ASI berfungsi sebagai stimulan pertumbuhan sel epitel khususnya epitel saluran cerna. Faktor anti-infeksi pada ASI seperti imunoglobulin, komponen seluler dan sitokin berfungsi sebagai bakterisida, antivirus, dan antijamur. Faktor-faktor ini diyakini berkontribusi terhadap penurunan insidensi enterokolitis 
nekrotikans, infeksi saluran pernapasan, dan penyakit saluran cerna lainnya pada bayi yang disusui $[3,7]$.

Karakteristik sampel ibu sebagian besar tidak didapatkan riwayat eklampsia (79\%) dan hanya $21 \%$ yang memiliki riwayat preeklampsia/ eklampsia, berbeda bermakna secara statistik menurut kelompok usia kehamilan $(\mathrm{p}=0,00)$. Hasil penelitian ini sesuai dengan hasil penelitian lain yang menyimpulkan bahwa eklampsia memiliki hubungan kausatif dan merupakan faktor risiko kelahiran prematur [13]. Kelahiran secara seksio sesaria didapatkan pada sebagian besar (62\%) sampel penelitian ini. Penelitian lain juga menunjukkan hal yang sama bahwa terdapat peningkatan prevalensi tindakan seksio sesaria pada kelahiran prematur [14].

Hasil penelitian ini menunjukkan kadar IGF-1 ASI berbeda bermakna antar kelompok usia kehamilan dan kadarnya juga berbeda antara ASI kolostrum dan ASI transisi. Peneliti lain membuktikan bahwa kadar IGF-1 dalam ASI tertinggi pada akhir kehamilan dan awal laktasi, kemudian mengalami penurunan setelahnya [15]. Hal ini terjadi bersamaan dengan jumlah reseptor IGF-1 yang lebih banyak pada awal kehamilan dibandingkan dengan akhir kehamilan dan laktasi [16]. Hasil penelitian berbeda dengan hasil peneliti lain yang membuktikan bahwa ASI dari ibu neonatus prematur memiliki kadar IGF-I yang tinggi, tetapi rerata kadarnya tidak berbeda secara signifikan antara ASI dari ibu dengan neonatus aterm dan prematur [17]. Kadar IGF-1 ASI transisi berbanding lurus dengan usia kehamilan ibu, semakin tua usia kehamilan ibu diikuti peningkatan kadar IGF-I transisi [18].

Hasil penelitian ini menunjukkan kadar EGF ASI berbeda bermakna antar kelompok usia kehamilan dan kadarnya juga berbeda antara ASI kolostrum dan ASI transisi. Penelitian Khodabakhshi et al, 2015 membuktikan bahwa konsentrasi EGF dari ASI neonatus dengan berat badan yang sesuai masa kehamilan (SMK) memiliki nilai yang lebih tinggi daripada EGF ASI neonatus dengan berat badan yang besar masa kehamilan (BMK) $(\mathrm{p}=0.01) \quad$ [19]. Beberapa penelitian menunjukkan kadar EGF ASI lebih tinggi pada ASI kolostrum dibandingkan ASI transisi, EGF ASI kolostrum neonatus prematur lebih tinggi dibandingkan aterm, dan kadar EGF ASI sangat tergantung pada asupan nutrisi ibu [20,21]. Hasil penelitian ini berbeda dengan hasil yang penelitian yang dilakukan oleh Castellote et al, 2011 yang mengatakan bahwa kadar EGF ASI transisi neonatus prematur 28-32 minggu lebih tinggi dibandingkan dengan aterm. Hal tersebut dapat dijelaskan bahwa ada kemungkinan pada neonatus prematur usia kehamilan kurang dari 30 minggu, adaptasi laktasinya tidak seefisien neonatus aterm. Hal ini terjadi ketika dalam kondisi fisiologis normal neonatus tidak diharapkan lahir, ASI tidak dapat mengimbangi kondisi tersebut. Mekanisme laktasi (laktogenesis) pada ibu hamil, dimulai sejak pertengahan kehamilan (tahap I), kemudian akhir kehamilan hingga hari ke-4 postpartum (tahap II), dan hari ke-10 post-partum hingga tahap involusi (tahap III) [22]. Menurut peneliti lain yang membandingkan kadar VEGF, HGF dan EGF pada kolostrum menemukan bahwa kadar konsentrasi VEGF, HGF dan EGF pada neonatus aterm lebih tinggi daripada neonatus prematur. Kadar EGF yang tinggi diperlukan dalam pertumbuhan neonatus [23].

Peptida antimikroba yang terkandung pada ASI terdiri dari cathelicidin, defensin (hBD-1 dan hBD-2), laktoferin, laktoperoksidase dan lisozim. Defensin pada neonatus berfungsi melindungi permukaan epitel saluran cerna, saluran napas dan kulit dari kolonisasi mikroba 
serta memodulasi potensi netrofil, makrofag dan sel mast [24].

Hasil penelitian ini menunjukkan kadar hBD-1 ASI berbeda bermakna antar kelompok usia kehamilan dan kadarnya juga berbeda antara ASI kolostrum dan ASI transisi. Kadar hBD-1 ASI kolostrum dan transisi tertinggi ditemukan pada kelompok aterm. Penelitian ini didukung peneliti lain yang menemukan hBD-1 terdeteksi dalam ASI dalam konsentrasi $1-10 \mu \mathrm{g} / \mathrm{mL}$ [25]. Hasil ini berbeda dengan penelitian Castellote et al., 2011 bahwa konsentrasi hBD-1 pada sampel ASI kolostrum lebih tinggi dibandingkan ASI transisi dan matur pada usia kehamilan prematur [22].

Hasil penelitian ini menunjukkan bahwa kadar hBD-2 ASI berbeda bermakna antar kelompok usia kehamilan. Epitel saluran pernapasan merupakan salah satu organ yang mampu menghasilkan hBD-2 terutama ketika mengalami inflamasi [26]. Kadar hBD-2 berhubungan dengan prognosis pneumonia yakni pasien dengan kadar hBD 2 plasma yang rendah memiliki risiko lebih tinggi terjadi pneumonia berat, penggunaan ventilator bahkan kematian [27].

Hasil penelitian ini menunjukkan bahwa kadar IL-8 ASI berbeda bermakna antar kelompok usia kehamilan dan kadarnya lebih tinggi pada neonatus kurang bulan. Berbeda dengan penelitian Polat et al, 2016 yang menyebutkan bahwa terdapat penurunan kadar IL-8 sesuai dengan tahap periode laktasi (kolostrum, transisi, dan matur), namun tidak ada perbedaan bermakna antara neonatus prematur dan aterm [28].

Keterbatasan penelitian ini sebagai berikut: 1) jumlah sampel kecil dan metode pengambilan sampel menggunakan consecutive sampling, 2) pengukuran faktor pertumbuhan dan sitokin hanya dilakukan 2 kali (periode ASI kolostrum dan transisi), 3) sampel yang diambil hanya pada ASI ibu, belum ada perbandingan pada sampel serum ibu dan neonatus, ataupun sampel non-invasif lain seperti urin/tinja, 4) Parameter penelitian lain yang terkait hormon dan faktor pertumbuhan (misalnya IGF-II, IGFBP, Growth Hormone, prolaktin), serta sitokin lain (misalnya IL-6, IL-10, TNF- $\alpha$ ) belum dilakukan, 5) peneliti belum mengkaji karakteristik responden yang terkait produksi ASI dan faktor pertumbuhan.

\section{SIMPULAN}

Kadar faktor pertumbuhan dan sitokin (IGF-1, EGF, hBD-1, hBD-2, IL-8) berbeda antar usia kehamilan. Kadar faktor pertumbuhan dan sitokin (IGF-1, EGF dan hBD-1) berbeda antara ASI kolostrum dan ASI transisi. Tren kadar faktor pertumbuhan IGF-1, EGF, dan hBD-1 tinggi pada neonatus cukup bulan. Kadar hBD-2 dan IL-8 tinggi pada neonatus kurang bulan. Berdasarkan hasil penelitian ini, ASI sebagai satu-satunya pilihan nutrisi untuk bayi baru lahir, mengandung faktor pertumbuhan dan sitokin yang bermanfaat untuk pertumbuhan sel epitel dan pertahanan imun bayi, kadarnya berubah seiring dengan usia kehamilan dan maturitas ASI.

\section{DAFTAR PUSTAKA}

1. Bhatia J. Human Milk for Preterm Infants and Fortification. Basel: Karger AG. Nestlé Nutr Inst Workshop Ser. 2016; 86: 109-119.

2. Fleig L, Hagan J, Lee ML, et al. Growth Outcomes of Small for Gestational Age Preterm Infants Before and After Implementation of an Exclusive Human Milk-Based Diet. J Perinatol [serial online]. 2021; 1-6. (Diunduh 15 Juli 2021). Available from: https://www.nature.com/jp/

3. Leghi GE, Middleton PF, Muhlhausler BS. A Methodological Approach to Identify the Most 
Reliable Human Milk Collection Method for Compositional Analysis: A Systematic Review Protocol. Syst Rev. 2018; 7: 122.

4. Collado MC, Santaella M, Mira-Pascual L, Martínez-Arias E, Khodayar-Pardo P, Ros G, et al. Longitudinal Study of Cytokine Expression, Lipid Profile and Neuronal Growth Factors in Human Breast Milk from Term and Preterm Deliveries. Nutrients. 2015; 7 (10): 8577-91.

5. Patel AL, Johnson TJ, Engstrom JL, Fogg LF, Jegier BJ, Bigger HR, et al. Impact of Early Human Milk on Sepsis and Health-Care Costs in Very Low Birth Weight Infants. J Perinatol. 2013; 33 (7): 514-519.

6. Trend S, Strunk T, Lloyd ML, Kok $\mathrm{CH}$, Metcalfe J, Geddes DT, et al. Levels of Innate Immune Factors in Preterm and Term Mother's Breast Milk During the 1st Month Postpartum. British Journal of Nutrition. 2016; 115: 1178-1193.

7. Heinig K, Sage F, Robin C, Sperandio M. Development and Trafficking Function of Haematopoietic Stem Cells and Myeloid Cells During Fetal Ontogeny. Cardiovasc Res. 2015; 107 (3): 352-63.

8. R\&D Systems. Quantikine Human IGF-1 ELISA Kit. User Manual. [Dokumen di Internet]. USA: R\&D Systems Inc; 2014. (Diunduh 19 Januari 2020). Available from: https://resources.rndsystems.com/pdf s/datasheets/dg100.pdf.

9. R\&D Systems. Quantikine Human EGF ELISA Kit. User Manual. [Dokumen di Internet]. USA: R\&D Systems Inc; 2014. (Diunduh 19 Januari 2020). Available from: https://resources.rndsystems.com/pdf s/datasheets/deg00.pdf.

10. R\&D Systems. Quantikine Human IL-8/CXCL 8 ELISA Kit. User
Manual. [Dokumen di Internet]. USA: R\&D Systems Inc; 2014. (Diunduh 19 Januari 2020). Available from: https://resources.rndsystems.com/pdf s/datasheets/d8000c.pdf.

11. R\&D Systems. Human beta-Defensin 2 Antibody. User Manual. [Dokumen di Internet]. USA: R\&D Systems Inc; 2014. (Diunduh 19 Januari 2020). Available from: https://resources.rndsystems.com/pdf s/datasheets/af2758.pdf.

12. Dahlan S. Statistik untuk Kedokteran dan Kesehatan, Edisi 5. Jakarta: Salemba Medika. 2011; 11-15.

13. Reza O, Mehdi R, Payam A, Arezoo E, Mahdi S, Amir A. Adverse Maternal and Neonatal Outcomes in Women with Preeclampsia in Iran. The Journal of Maternal-Fetal and Neonatal Medicine. 2017; 32: 212-216.

14. Delnord M, Béatrice B, Nicolas D, Kari K, Francisco B, Ashna M, et al. Varying Gestational Age Patterns in Cesarean Delivery: an International Comparison. BMC Pregnancy and Childbirth. 2014; 14: 321.

15. Gila-Diaz A, Arribas SM, Algara A, Martín-Cabrejas MA, López de Pablo ÁL, Sáenz de Pipaón M, et al. A Review of Bioactive Factors in Human Breastmilk: A Focus on Prematurity. Nutrients. 2019; 11 (6): 1307.

16. Kazimierska K, Kalinowska-Lis U. Milk Proteins-Their Biological Activities and Use in Cosmetics and Dermatology. Molecules. 2021; 26 (11): 3253.

17. Serrao F, Papacci P, Costa S, Giannantonio C, Cota F, Vento G, Romagnoli C. Effect of Early Expressed Human Milk on Insulin-Like Growth Factor 1 and Short-Term Outcomes in Preterm Infants. PLoS One. 2016; 11 (12): e0168139. 
18. Vidal AC, Murtha AP, Murphy SK, Fortner K, Overcash F, Henry N, etal. Maternal BMI, IGF-I Levels, and Birth Weight in African American and White Infants. International Journal of Pediatrics. 2013; 2013: 191472.

19. Khodabakhshi A, Ghayour-Mobarhan M, Rooki H, Vakili R, Hashemy S-I, Mirhafez SR, et al. Comparative Measurement of Ghrelin, Leptin, Adinopectin, EGF, and IGF-1 in Breast Milk of Mothers with Overweight/Obese and Normal-Weight Infants. European Journal of Clinical Nutrition. 2015; 69: 614-618.

20. Lu M, Jiang J, Wu K, Li D. Epidermal Growth Factor and Transforming Growth Factor- $\alpha$ in Human Milk of Different Lactation Stages and Different Regions and Relationship with Maternal Diet. Food Funct. 2018; 9: 1199-1204.

21. Sood S, Gupta A. Colostrum-Miraculous Fluid. International Journal of Management and Humanities. 2017; 4 (1): 1-5.

22. Castellote C, Casillas R, Santana CR, Perez-Cano FJ, Castell M, Moretones MG, et al. Premature Delivery Influences the Immunological Composition of Colostrum and Transitional and Mature Human Milk. The Journal of Nutrition. 2011; 141 (6): 1181-1187.
23. Munblit D, Abrol P, Sheth S, Chow LY, Khaleva E, Asmanov A, et al. Levels of Growth Factors and IgA in the Colostrum of Women from Burundi and Italy. Nutrients. 2018; 10 (9): 1216.

24. Monaco MH, Kim J, Donovan SM. Human Milk: Composition and Nutritional Value. Dalam: Caballero B, Finglas PM, Toldra F, editor. Encyclopedia of Food and Health. Vol 1. Amsterdam: Elsevier BV. 2016: 357-362.

25. Wheeler TT, Smolenski GA, Harris DP, Gupta SK, Haigh BJ, Broadhurst MK, et al. Host-Defence-Related Proteins in Cows' Milk. Animal. 2012; 6 (3): 415-22.

26. Prasad SV, Fiedoruk K, Daniluk T, Piktel E, Bucki R. Expression and Function of Host Defense Peptides at Inflammation Sites. Int $\mathrm{J}$ Mol Sci. 2019; 21(1): 104.

27. Hackam DJ, Sodhi CP. Toll-Like Receptor-Mediated Intestinal Inflammatory Imbalance in the Pathogenesis of Necrotizing Enterocolitis. Cell Mol Gastroenterol Hepatol. 2018; 6 (2): 229-238.e1.

28. Polat A, Tunc T, Erdem G, Yerebazmaaz N, Tas A, Beken S. Interleukin-8 and Its Receptors in Human Milk from Mothers of Full-Term and Premature Infants. Breastfeeding Medicine. 2016; 11: 5. 